\title{
Strategi Pencegahan Pembiayaan Bermasalah pada BPRS di Kabupaten Bogor
}

\section{Default Financing Prevention Strategy of BPRS in Kabupaten Bogor}

\author{
Aulia Nur Cahyani ${ }^{1}$, Neneng Hasanah ${ }^{2}$, Mohammad Iqbal Irfany ${ }^{3}$ \\ ${ }^{1}$ Institut Pertanian Bogor, Jalan Raya Dramaga, Bogor 16680, auliaanurcahyani @ gmail.com \\ ${ }^{2}$ Institut Pertanian Bogor, Jalan Raya Dramaga, Bogor 16680, nenengnajaah3@gmail.com \\ ${ }^{3}$ Institut Pertanian Bogor, Jalan Raya Dramaga, Bogor 16680, iqbal.irfany @ g mail.com
}

\begin{abstract}
Financing is channeling funds carried out by Islamic banks, such as Islamic rural banks (BPRS). Risk arising from financing is default risk assessed by the ratio of Non Performing Financing $(N P F) . B P R S$ in the area of Kabupaten Bogor have NPF values above the safe limit set by Bank Indonesia. The purpose of this study is to identify the causes and solutions of default financing and formulate strategies for preventing default financing of BPRS in Kabupaten Bogor. The method used in this study is Analytic Network Process (ANP). The total respondents in this study are five. The result showed that external cause is the most influential factor towards the occurrence of default financing. The most influential external cause is customer's bad intention. External solution is the priority solution that need special attention. The priority external solution is strengthening the analysis. The most influential internal cause is adverse selection. Internal solution that is prioritized is training for finance officers. The priority of the default financing prevention strategy in this study is formulating financing risk mitigation.
\end{abstract}

Keywords: ANP, BPRS, default financing, prevention strategy

\begin{abstract}
Abstrak. Pembiayaan merupakan kegiatan penyaluran dana yang dilakukan oleh bank syariah, salah satunya oleh Bank Pembiayaan Rakyat Syariah (BPRS). Risiko yang timbul akibat adanya pembiayaan yaitu risiko gagal bayar, yang dinilai dengan rasio Non Performing Financing (NPF). BPRS di wilayah Kabupaten Bogor memiliki nilai NPF di atas batas aman yang ditetapkan Bank Indonesia. Tujuan dari penelitian ini adalah mengidentifikasi penyebab dan solusi pembiayaan bermasalah serta merumuskan strategi pencegahan pembiayaan bermasalah pada BPRS di Kabupaten Bogor. Metode yang digunakan dalam penelitian ini adalah Analytic Network Process (ANP). Total responden dalam penelitian ini berjumlah lima orang. Hasil penelitian menunjukkan bahwa penyebab eksternal menjadi hal yang paling berpengaruh terhadap terjadinya pembiayaan bermasalah. Penyebab eksternal yang paling berpengaruh adalah iktikad tidak baik nasabah. Solusi eksternal menjadi prioritas solusi yang harus mendapat perhatian khusus. Solusi eksternal yang menjadi prioritas adalah penguatan analisis awal. Penyebab internal yang paling berpengaruh adalah adverse selection. Solusi internal yang menjadi prioritas adalah pelatihan bagi petugas pembiayaan. Adapun prioritas strategi pencegahan pembiayaan bermasalah pada penelitian ini adalah penyusunan mitigasi risiko pembiayaan.
\end{abstract}

Kata kunci: ANP, BPRS, pembiayaan bermasalah, strategi pencegahan

\section{PENDAHULUAN}

Berdasarkan Undang-Undang No. 21 Tahun 2008, kegiatan bank syariah secara umum yaitu menghimpun dan menyalurkan dana, baik untuk Bank Umum Syariah (BUS), Unit Usaha Syariah (UUS), maupun Bank Pembiayaan Rakyat Syariah (BPRS). Salah satu bentuk penyaluran dana kepada masyarakat adalah pembiayaan. Pembiayaan atau dalam istilah teknisnya disebut aktiva produktif, menurut Peraturan Bank Indonesia No. 5/7/PBI/2003 memiliki arti penyediaan dana dan atau tagihan berdasarkan akad mudharabah dan atau musyarakah dan atau pembiayaan lainnya berdasarkan prinsip bagi hasil.

Bank Pembiayaan Rakyat Syariah (BPRS) sebagai bagian dari bank syariah juga melakukan aktivitas penyaluran dana kepada masyarakat dalam bentuk pembiayaan. Berdasarkan data Otoritas Jasa Keuangan (OJK), komposisi pembiayaan yang diberikan oleh Bank Pembiayaan Rakyat Syariah (BPRS) berdasarkan akad periode Januari - Mei 2019 adalah sebagai berikut: 


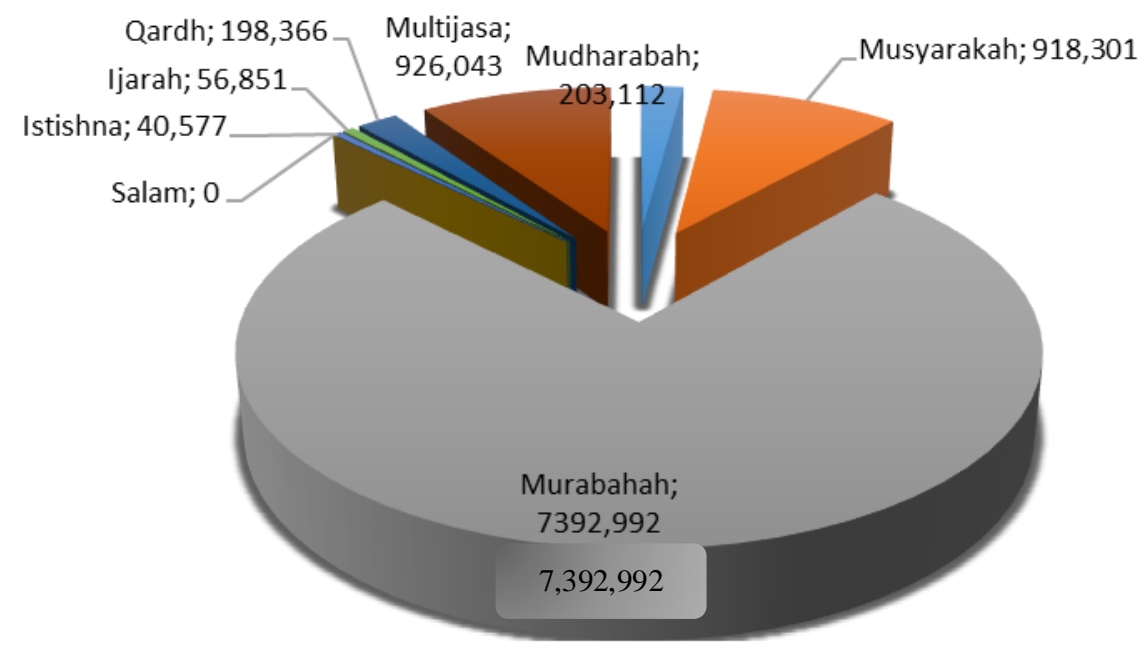

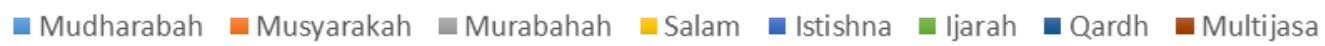

Sumber: Otoritas Jasa Keuangan, 2019 (diolah)

Gambar 1 Komposisi pembiayaan yang diberikan BPRS (juta rupiah)

Pembiayaan murabahah memiliki komposisi paling besar yaitu mencapai 7,392,992 juta rupiah, kemudian diikuti oleh pembiayaan multijasa sebesar 926,043 juta rupiah, musyarakah sebesar 918,301 juta rupiah, mudharabah sebesar 203,112 juta rupiah, qardh sebesar 198,366 juta rupiah, ijarah sebesar 56,851 juta rupiah, dan istishna sebesar 40,577 juta rupiah. Pembiayaan salam sebesar 0, artinya tidak ada penyaluran dana dalam bentuk pembiayaan salam per Mei 2019.

Menurut Susilo (2017), aset bank syariah dalam bentuk pembiayaan dapat menjadi salah satu sumber risiko apabila dalam penyalurannya tidak disertai prinsip kehati-hatian (prudent). Risiko kredit atau risiko pembiayaan adalah risiko yang timbul akibat adanya kegagalan nasabah atau debitur dalam memenuhi kewajibannya. Berdasarkan Pasal 4 Surat Keputusan Direktur Bank Indonesia Nomor 30/267/KEP/DIR, penggolongan kualitas pembiayaan terbagi menjadi lima golongan pembiayaan yaitu lancar, dalam perhatian khusus, kurang lancar, diragukan, dan macet. Adapun pembiayaan nonlancar terdiri dari kualitas pembiayaan kurang lancar, diragukan, dan macet. Jumlah pembiayaan nonlancar pada BPRS mengalami peningkatan dalam lima tahun terakhir. Hal ini dibuktikan dengan adanya pergeseran garis pada grafik (Gambar 2). Garis bergeser ke atas, artinya jumlah pembiayaan nonlancar pada BPRS relatif meningkat setiap tahunnya. 


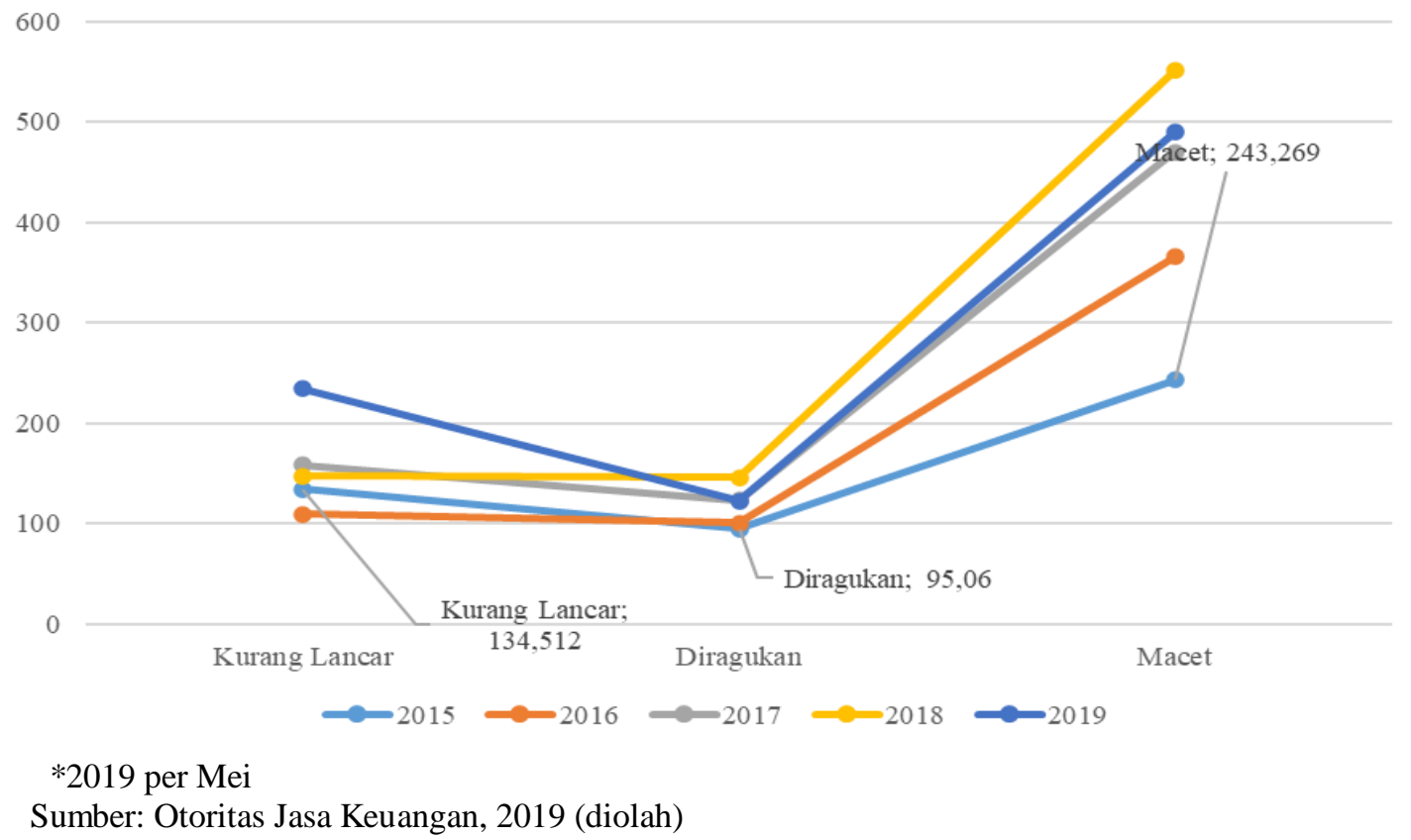

Gambar 2 Pembiayaan BPRS berdasarkan kolektabilitas nonlancar (juta rupiah)

Peningkatan jumlah pembiayaan non lancar atau pembiayaan bermasalah berdampak kepada peningkatan nilai rasio Non Performing Financing (NPF). Menurut Ibrahim \& Rahmati (2017), semakin besar alokasi pembiayaan yang diberikan oleh bank, maka semakin besar pula risiko timbulnya pembiayaan bermasalah. NPF merupakan rasio antara total pembiayaan kategori nonlancar yang diberikan dengan total pembiayaan yang diberikan. Batas aman nilai rasio NPF BPRS berdasarkan Surat Edaran Bank Indonesia Nomor 9/29/PBI/DPbs Tahun 2007 tentang Penilaian Tingkat Kesehatan Bank Perkreditan Rakyat Berdasarkan Prinsip Syariah (TKS-BPRS) adalah sebesar 7\%. Berdasarkan data Otoritas Jasa Keuangan (OJK), nilai rasio NPF BPRS di Indonesia selama lima tahun berturut-turut berada di atas 7\% (Gambar 3).

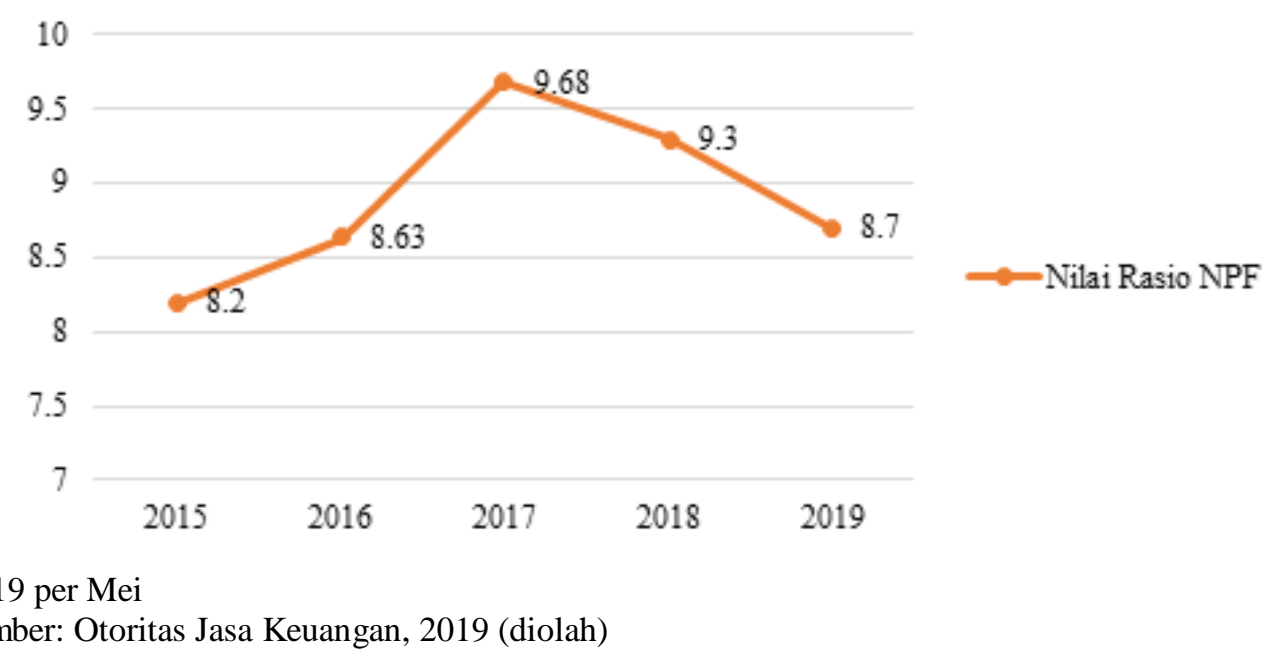

Gambar 3 Rasio NPF BPRS di Indonesia

Kabupaten Bogor merupakan wilayah yang memiliki kantor pusat BPRS terbanyak di wilayah Provinsi Jawa Barat, yaitu sebanyak lima kantor pusat (Tabel 1). BPRS dengan kantor pusat di wilayah Kabupaten Bogor yaitu PT. BPR Syariah Amanah Ummah, PT. BPR Syariah Bina Rahmah, PT. BPRS Rif'atul Ummah, PT. BPRS Insan Cita Artha Jaya, dan BPRS Bogor Tegar Beriman. 
Tabel 1 Jumlah kantor pusat BPRS di wilayah Provinsi Jawa Barat

\begin{tabular}{lc}
\hline \multicolumn{1}{c}{ Wilayah } & Jumlah \\
\hline Kabupaten Bogor & 5 \\
Kabupaten Bandung & 4 \\
Kota Depok & 4 \\
Kabupaten Bekasi & 3 \\
Kota Bekasi & 3 \\
Kabupaten Garut & 2 \\
Kota Bandung & 2 \\
Kota Tasikmalaya & 2 \\
Kabupaten Cianjur & 1 \\
Kabupaten Subang & 1 \\
Kota Cimahi & 1 \\
\hline Sumber: Otoritas Jas Keung
\end{tabular}

Sumber: Otoritas Jasa Keuangan, 2019 (diolah)

Berdasarkan data Otoritas Jasa Keuangan, nilai rasio NPF BPRS di Kabupaten Bogor melebihi batas aman NPF yang ditetapkan Bank Indonesia yaitu 7\% (Tabel 2). Pada tahun 2017, nilai rasio NPF dari keempat BPRS di wilayah Kabupaten Bogor yaitu BPRS B, BPRS C, BPRS D, dan BPRS E, berada di atas 7\%. Pada tahun 2018, BPRS dengan nilai rasio NPF melebihi 7\% adalah BPRS B, BPRS C, dan BPRS E.

Tabel 2 Nilai rasio NPF BPRS Kabupaten Bogor pada tahun 2017-2018

\begin{tabular}{cccc}
\hline \multirow{2}{*}{ No. } & \multirow{2}{*}{ Nama BPRS } & $\mathbf{2 0 1 7}$ & $\mathbf{2 0 1 8}$ \\
\hline 1. & BPRS A & 3.31 & 3.31 \\
2. & BPRS B & 38.87 & 50.72 \\
3. & BPRS C & 15.76 & 10.82 \\
4. & BPRS D & 8.25 & 2.95 \\
5. & BPRS E & 18.08 & 22.94 \\
\hline
\end{tabular}

Sumber: Otoritas Jasa Keuangan, 2019 (diolah)

Kondisi tersebut merupakan salah satu bentuk fraud, karena dapat menimbulkan dampak kerugian untuk BPRS, nasabah, ataupun pihak lain yang memiliki kepentingan dengan BPRS. Fraud menurut Surat Edaran BI No. 13/28/DPNP adalah tindakan penyimpangan atau pembiaran yang sengaja dilakukan untuk mengelabui, menipu, atau memanipulasi bank, nasabah, atau pihak lain, yang terjadi di lingkungan bank dan/atau menggunakan sarana bank sehingga mengakibatkan bank, nasabah, atau pihak lain menderita kerugian dan/atau pelaku fraud memperoleh keuntungan keuangan baik secara langsung maupun tidak langsung. Salah satu pilar strategi penerapan antifraud yang tertuang dalam Surat Edaran BI No. 13/28/DPNP yaitu pencegahan. Pilar pencegahan ini memuat perangkatperangkat yang digunakan untuk mengurangi risiko terjadinya fraud. Oleh karena itu, strategi pencegahan sebagai salah satu pilar strategi penerapan antifraud, dapat dijadikan alat untuk mengurangi dampak kerugian akibat adanya risiko pembiayaan (pembiayaan bermasalah) pada BPRS di Kabupaten Bogor.

Menurut UU perbankan syariah pasal 37 ayat (1), penyaluran dana yang mengandung risiko kegagalan atau kemacetan dapat berpengaruh terhadap kesehatan bank syariah tersebut. Pembiayaan bermasalah pada bank syariah dapat menurunkan kemampuan bank dalam memperoleh pendapatan serta memperbesar biaya Penyisihan Penghapusan Aktiva Produktif atau PPAP (Djamil, 2012). Penyisihan Penghapusan Aktiva Produktif (PPAP) adalah upaya kebijaksanaan penyisihan terhadap penghapusan aktiva produktif atas risiko kerugian kredit yang timbul akibat kolektabilitas dalam artian nyata. Selain itu, pembiayaan bermasalah dapat memperburuk citra bank dan turunnya kepercayaan masyarakat. Jika pembiayaan bermasalah melampaui batas, maka akan menjadi masalah serius yang akan mengganggu profitabilitas bank syariah yang berujung pada berhentinya operasional terutama pada bank syariah yang memiliki aset kecil seperti pada BPRS (Firmansyah, 2014). 
Rasio NPF BPRS di Kabupaten Bogor perlu mendapat perhatian khusus dari masing-masing pihak BPRS karena sudah melebihi batas aman yang ditentukan Bank Indonesia (BI). Demi menjaga kesehatannya, Bank Pembiayaan Rakyat Syariah (BPRS) di Kabupaten Bogor perlu mengetahui penyebab terjadinya pembiayaan bermasalah. Selain itu, rumusan solusi serta strategi untuk mencegah pembiayaan bermasalah juga sangat dibutuhkan dalam mempertahankan kelangsungan BPRS di Kabupaten Bogor.

\section{TINJAUAN PUSTAKA}

Istilah pembiayaan bermasalah atau Non Performing Financing (NPF) dapat ditemukan pada laporan Statistik Perbankan Syariah (SPS) yang diterbitkan oleh Direktorat Perbankan Syariah Otoritas Jasa Keuangan. Pembiayaan bermasalah adalah kategori pembiayaan nonlancar dengan kolektabilitas kurang lancar, diragukan, dan macet.

Djamil (2012) mengatakan bahwa segi produktivitas pembiayaan bermasalah dalam kaitannya dengan kemampuan menghasilkan pendapatan bagi bank, ditunjukkan dengan menurunnya pendapatan bank dan meningkatnya biaya pencadangan yaitu PPAP (Penyisihan Penghapusan Aktiva Produktif). Sedangkan dari segi nasional, serta dalam skala nasional dapat mengurangi kontribusi terhadap pembangunan dan pertumbuhan ekonomi.

Bank Pembiayaan Rakyat Syariah menurut Undang-Undang No. 21 Tahun 2008 tentang Perbankan Syariah adalah bank yang melaksanakan kegiatan usahanya berdasarkan prinsip syariah. Adapun kegiatan usaha tersebut diantaranya adalah:

a. Menghimpun dana dalam bentuk simpanan tabungan berdasarkan akad wadiah, serta investasi dalam bentuk deposito atau tabungan, berdasarkan akad mudharabah atau pun akad lain yang sesuai dengan prinsip syariah.

b. Menyalurkan dana dalam bentuk pembiayaan bagi hasil (mudharabah dan musyarakah), pembiayaan berdasarkan akad murabahah, salam, istishna, qardh, pembiayaan sewa (ijarah), serta pembiayaan sewa beli (ijarah muntahiya bit tamlik).

c. Menempatkan dana kepada bank syariah lain dengan akad wadiah atau akad lain yang sesuai dengan prinsip syariah.

d. Memindahkan uang melalui rekening yang ada di BUS, bank konvensional, dan UUS.

e. Menyediakan produk yang sesuai dengan prinsip syariah.

Ibrahim \& Rahmati (2017) melakukan penelitian mengenai solusi pembiayaan bermasalah pada bank syariah dengan fokus kajian produk murabahah di BMI Banda Aceh. Penelitian ini menunjukkan besarnya pembiayaan bermasalah merupakan akibat dari besaran alokasi yang disalurkan oleh bank untuk pembiayaan yang tidak disertai dengan manajemen risiko yang baik. Faktor-faktor yang menjadi penyebab terjadinya pembiayaan bermasalah pada BMI Banda Aceh dibagi menjadi tiga kategori yaitu internal, eksternal, dan fiktif.

Faktor internal terdiri dari kelemahan dalam analisis pembiayaan, pembiayaan di bawah kebutuhan nasabah (under-financing), jangka waktu pembayaran, kurangnya kontrol dari pihak bank, kurang optimal dalam menyaring risiko, serta kurangnya SDM di bidang relevan. Faktor eksternal (nasabah) yaitu adanya iktikad tidak baik dari nasabah, pendapatan nasabah yang menurun, musibah yang dialami nasabah, kurang profesional dalam mengelola usaha, serta kecerobohan nasabah dalam mengelola dana. Sedangkan faktor fiktif terdiri dari fiktif pembiayaan dan fiktif jaminan.

Rahayu \& Hendrianto (2018) dalam penelitannya yang berjudul "Mitigasi Risiko Pembiayaan pada Bank Perkreditan Rakyat Syariah (BPRS) SAFIR Cabang Curup Kabupaten Rejang Lebong" menyatakan bahwa risiko yang dihadapi oleh BPRS SAFIR yang memiliki dampak besar adalah risiko kredit dan risiko strategi. Risiko kredit disebabkan oleh kesalahan dari pihak nasabah. Kesalahan ini bisa disebabkan oleh beberapa hal, yaitu perubahan keadaan ekonomi atau watak dari nasabah yang tidak memiliki iktikad baik untuk melunasi kewajibannya. Sedangkan risiko strategi 
muncul karena kesalahan pihak bank. Risiko strategi sangat memiliki pengaruh besar bagi kelangsungan usaha bank. Jika bank salah langkah dalam memilih strategi yang tidak sesuai dengan kondisi eksternal bank, maka apa pun yang direncanakan bank di awal tidak akan berjalan dengan baik.

Tindakan mitigasi risiko pembiayaan BPRS SAFIR ialah menghindari dan mengurangi risiko. Mitigasi menghindari risiko dilakukan dengan melakukan evaluasi mendalam terhadap usaha dan karakter calon nasabah penerima fasilitas pembiayaan. Kemudian mitigasi kedua yang dilakukan BPRS SAFIR yaitu mengurangi risiko dengan penetapan syarat-syarat tertentu untuk masing-masing pembiayaan yang harus dipenuhi calon nasabah penerima fasilitas, pengikatan jaminan berupa fixed asset dan movable asset, dan melakukan monitoring berkala.

Rodoni \& Yaman (2018) dalam penelitiannya dengan judul "Asymmetric Information and NonPerforming Financing: Study in The Indonesia Islamic Banking Industry" menyatakan bahwa asymmetric information (suatu kondisi di mana salah satu pihak memiliki lebih banyak informasi daripada pihak lain) pada pembiayaan mudharabah sebagai salah satu risiko moral hazard yaitu dengan adanya deviasi penyediaan fakta dan data. Studi kasus pada Bank BRI Syariah menyatakan bahwa nasabah mempunyai informasi keuangan lebih baik dibandingkan dengan pihak bank. Studi kasus pada Bank BJB Syariah menunjukkan bahwa moral hazard dilakukan oleh nasabah dengan melakukan duplikasi agunan. Selain itu, moral hazard juga disebabkan oleh pengabaian manajemen bank dalam melakukan verifikasi dokumen nasabah. Adverse selection (salah memilih nasabah) terjadi karena adanya ketidakterbukaan antara nasabah dengan bank.

\section{METODE}

Data yang digunakan dalam penelitian ini adalah data primer dan data sekunder. Data primer didapatkan dari hasil wawancara mendalam (indepth interview) mengenai pembiayaan bermasalah yang terjadi di BPRS Kabupaten Bogor kepada para pakar dan praktisi yang memiliki pemahaman terkait permasalahan. Tahap selanjutnya adalah pengisian kuesioner oleh para responden pada pertemuan kedua. Data sekunder didapatkan dari berbagai sumber seperti jurnal ilmiah, penelitian terdahulu, Bank Indonesia (BI), dan Otoritas Jasa Keuangan (OJK).

Penelitian ini dilakukan di tiga BPRS yang berlokasi di Kabupaten Bogor, yaitu BPRS Bina Rahmah, BPRS Amanah Ummah, dan BPRS Insan Cita Artha Jaya. Pemilihan lokasi dilakukan secara purposive (kriteria tertentu) dengan pertimbangan bahwa Kabupaten Bogor memiliki jumlah BPRS dengan kantor induk terbanyak se-wilayah Provinsi Jawa Barat. Pengambilan sampel dilakukan dengan menggunakan teknik non probability sampling (nonacak) dengan teknik pengambilan data menggunakan metode purposive sampling. Sampel dalam penelitian ini adalah tiga praktisi BPRS khususnya direksi dari BPRS bersangkutan, satu perwakilan regulator dalam bidang perbankan yaitu Otoritas Jasa Keuangan (OJK), serta satu orang akademisi. Total responden dalam penelitian ini berjumlah lima orang.

Metode yang digunakan untuk menganalisis data adalah Analytic Network Process (ANP). Metode ANP merupakan pengembangan dari metode AHP (Analytic Hierarchy Process). Interaksi berupa umpan balik baik dari elemen-elemen dalam klaster (inner dependence) maupun antarklaster (outer dependence) diizinkan dalam metode ANP. Software Super Decision 2.10 dan Microsoft Excel 2013 digunakan dalam mengolah dan menganalisis data. 
Tahapan penelitian pada metode ANP adalah sebagai berikut:

1. Konstruksi Model

Tahap ini merupakan tahap penyusunan model penelitian ANP yang disusun berdasarkan hasil studi literatur dan wawancara secara mendalam kepada para pakar dan praktisi. Para pakar dan praktisi yang dilibatkan memiliki pengetahuan mendalam terkait topik pembiayaan bermasalah khususnya pada BPRS di Kabupaten Bogor.

2. Kuantifikasi Model

Tahap ini merupakan tahap pengisian kuesioner ANP. Pertanyaan-pertanyaan yang digunakan dalam kuesioner adalah berupa perbandingan berpasangan (pairwise comparison). Tujuan dari tahap ini adalah untuk mengetahui tingkat prioritas di antara dua hal yang diperbandingkan. Pengukuran besar pengaruh dan kepentingan diukur melalui skala numerik 1 sampai dengan 9 (Tabel 3).

Tabel 3 Perbandingan skala

\begin{tabular}{cc}
\hline Intensity of Importance & Definition \\
\hline 1 & Equal importance \\
2 & Moderate importance \\
3 & \\
4 & Strong importance \\
5 & \\
6 & Very strong demonstrated importance \\
7 & \\
8 & Extreme importance \\
9 &
\end{tabular}

Sumber: Saaty, 2002

3. Sintesis dan Analisis

Data yang diperoleh dari responden kemudian diinput ke Software Super Decision. Output yang dihasilkan dari pengolahan adalah berupa prioritas dan supermatriks. Tahap selanjutnya adalah mencari nilai geometric mean (GMk), dan Kendall's Coefficient of Concordance. Nilai-nilai tersebut digunakan untuk mencari nilai rater agreement dengan bantuan Microsoft Excel.

a. Geometric Mean

Geometric mean berfungsi untuk mengetahui hasil penilaian dan pendapat dari para responden dalam satu kelompok. Kombinasi penilaian dari responden akan membentuk konsensus dengan bantuan pairwise comparison (perbandingan berpasangan). Geometric mean merupakan salah satu jenis perhitungan rata-rata dengan output berupa nilai yang memiliki suatu tendensi tertentu.

b. Rater Agreement

Rater agreement merupakan suatu nilai yang memiliki arti tingkat kesepakatan para responden terhadap masalah yang diperhitungkan dalam satu klaster. Perhitungan rater agreement menggunakan alat Kendall's Coefficient of Concordance. Tingkat kesesuaian yang sempurna ditunjukkan dengan nilai $\mathrm{W}=1$. Semakin mendekati nilai 0 , maka artinya jawaban bervariatif pada masing-masing responden. 


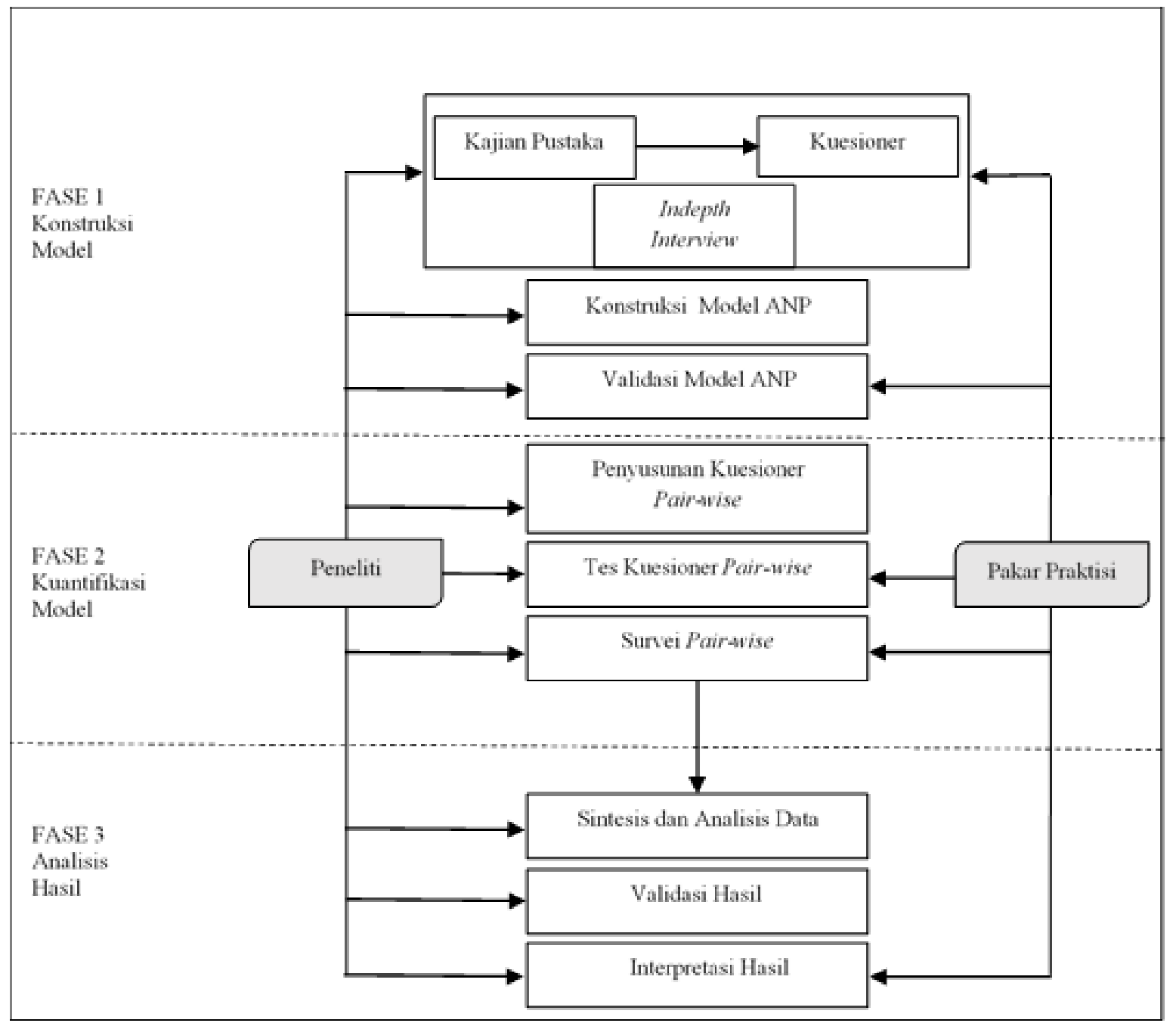

Sumber: Ascarya, 2011

Gambar 4 Tahapan ANP

\section{PEMBAHASAN}

Penelitian Strategi Pencegahan Pembiayaan Bermasalah pada BPRS di Kabupaten Bogor mengelompokkan beberapa aspek yaitu penyebab, solusi dan strategi berdasarkan studi literatur dan indepth interview (wawancara mendalam) yang dilakukan kepada para responden. Penyebab terjadinya pembiayaan bermasalah pada BPRS di Kabupaten Bogor terbagi ke dalam dua kelompok yaitu penyebab internal dan penyebab eksternal. Penyebab internal berasal dari internal BPRS. Sedangkan penyebab eksternal berasal dari eksternal berupa nasabah dan kondisi lainnya yang berada di luar BPRS. 


\begin{tabular}{|c|c|c|c|}
\hline & \multicolumn{2}{|c|}{$\begin{array}{c}\text { Strategi Pencegahan Pembiayaan Bermasalah } \\
\text { pada BPRS di Kabupaten Bogor }\end{array}$} & \\
\hline \begin{tabular}{ll} 
& \multicolumn{1}{c}{ PENYEBAB } \\
1. & $\begin{array}{l}\text { Penyebab Internal } \\
\text { Adverse Selection }\end{array}$ \\
2. & $\begin{array}{l}\text { Kekurangan jumlah } \\
\text { tenaga profesional }\end{array}$ \\
pembiayaan \\
3.
\end{tabular} & $\begin{array}{l}\text { STRATEGI } \\
\text { 1. Pembentukan komite } \\
\text { pembiayaan } \\
\text { 2. Penyusunan mitigasi } \\
\text { risiko } \\
\text { 3. Pembekalan petugas } \\
\text { pembiayaan } \\
\text { 4. Pemberian reward dan } \\
\text { punishment petugas } \\
\text { pembiayaan } \\
\text { 5. Optimalisasi } \\
\text { pengawasan } \\
\text { 6. Kunjungan rutin ke } \\
\text { nasabah }\end{array}$ & $\begin{array}{l}1 . \\
2 . \\
3 . \\
4 . \\
5 . \\
6 .\end{array}$ & \begin{tabular}{l}
\multicolumn{1}{c}{ SOLUSI } \\
Solusi Internal \\
Pengecekan SOP \\
pembiayaan secara \\
sistematis \\
Menata sistem \\
perekrutan \\
Pelatihan petugas \\
pembiayaan \\
Meningkatkan \\
intensitas monitoring \\
Evaluasi kebijakan \\
Pengawasan internal \\
dari kabag \\
pembiayaan \\
Solusi Eksternal \\
Meningkatkan \\
pelayanan \\
Menyeleksi nasabah \\
pembiayaan secara \\
cermat \\
Supervisi usaha \\
nasabah \\
Penguatan analisis \\
awal \\
Edukasi dan \\
monitoring \\
penggunaan dana \\
Pendekatan personal \\
nasabah
\end{tabular} \\
\hline
\end{tabular}

Sumber: Ilustrasi penulis, 2019

Gambar 5 Kerangka ANP penelitian 


\section{Penyebab Pembiayaan Bermasalah}

Penyebab terjadinya pembiayaan bermasalah pada BPRS di Kabupaten Bogor terbagi ke dalam dua kelompok yaitu penyebab internal dan penyebab eksternal. Nilai geometric mean (GMk) dari penyebab eksternal adalah sebesar 0.8 , sedangkan nilai geometric mean (GMk) penyebab internal sebesar 0.2. Hal tersebut mengindikasi bahwa penyebab yang paling berpengaruh terhadap pembiayaan bermasalah pada BPRS di Kabupaten Bogor berasal dari eksternal bank, sehingga penyebab eksternal harus mendapat perhatian khusus dari pihak bank. Nilai W yang dihasilkan dari perhitungan rater agreement adalah 1, yang berarti responden $100 \%$ sepakat akan hal ini atau dalam kata lain seluruh responden sepakat bahwa penyebab eksternal merupakan prioritas utama dalam menyumbang angka pembiayaan bermasalah pada BPRS di Kabupaten Bogor.

\section{PENYEBAB}

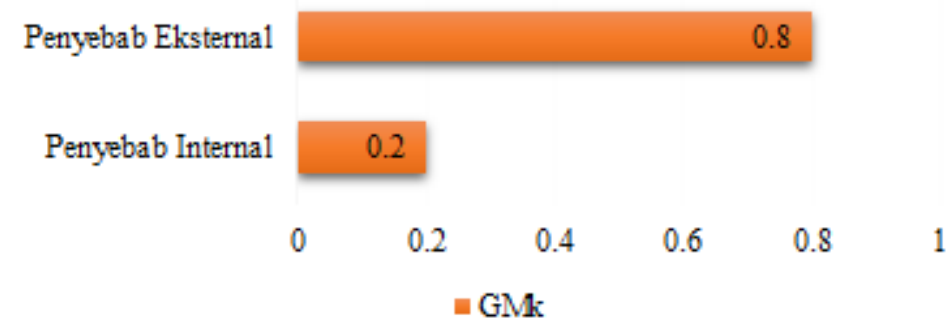

Sumber: Data primer, 2019 (diolah)

Gambar 6 Prioritas penyebab pembiayaan bermasalah

\section{Penyebab Internal Pembiayaan Bermasalah}

Penyebab internal merujuk kepada penyebab yang berasal dari BPRS. Penyebab internal terdiri dari adverse selection (salah memilih nasabah), kurangnya jumlah tenaga profesional bidang pembiayaan, kapabilitas SDM dalam menganalisis pembiayaan kurang memadai, lemahnya monitoring pembiayaan, kebijakan pembiayaan yang terlalu ekspansif, dan munculnya tindakan pidana pegawai BPRS. Gambar 7 menunjukkan tingkat prioritas penyebab internal penyumbang angka pembiayaan bermasalah pada BPRS di Kabupaten Bogor berdasarkan hasil olahan data yang diperoleh.

Prioritas pertama yaitu adanya adverse selection dengan nilai geometric mean sebesar 0.2110 . Urutan kedua yaitu kapabilitas SDM dalam menganalisis pembiayaan yang kurang memadai dengan nilai geometric mean sebesar 0.1889. Urutan ketiga yaitu kurangnya jumlah tenaga profesional dalam bidang pembiayaan dengan nilai geometric mean sebesar 0.1642 . Urutan keempat yaitu lemahnya monitoring pembiayaan dengan nilai geometric mean sebesar 0.1628 . Urutan kelima yaitu tindakan pidana pegawai BPRS dengan nilai geometric mean sebesar 0.1377. Urutan keenam yaitu kebijakan pembiayaan yang terlalu ekspansif dengan nilai geometric mean sebesar 0.1344 . Nilai W yang dihasilkan dari perhitungan rater agreement sebesar 0.3417. Hal ini berarti tingkat kesepakatan responden mencapai $34.17 \%$. 


\section{PENYEBAB INTERNAL}

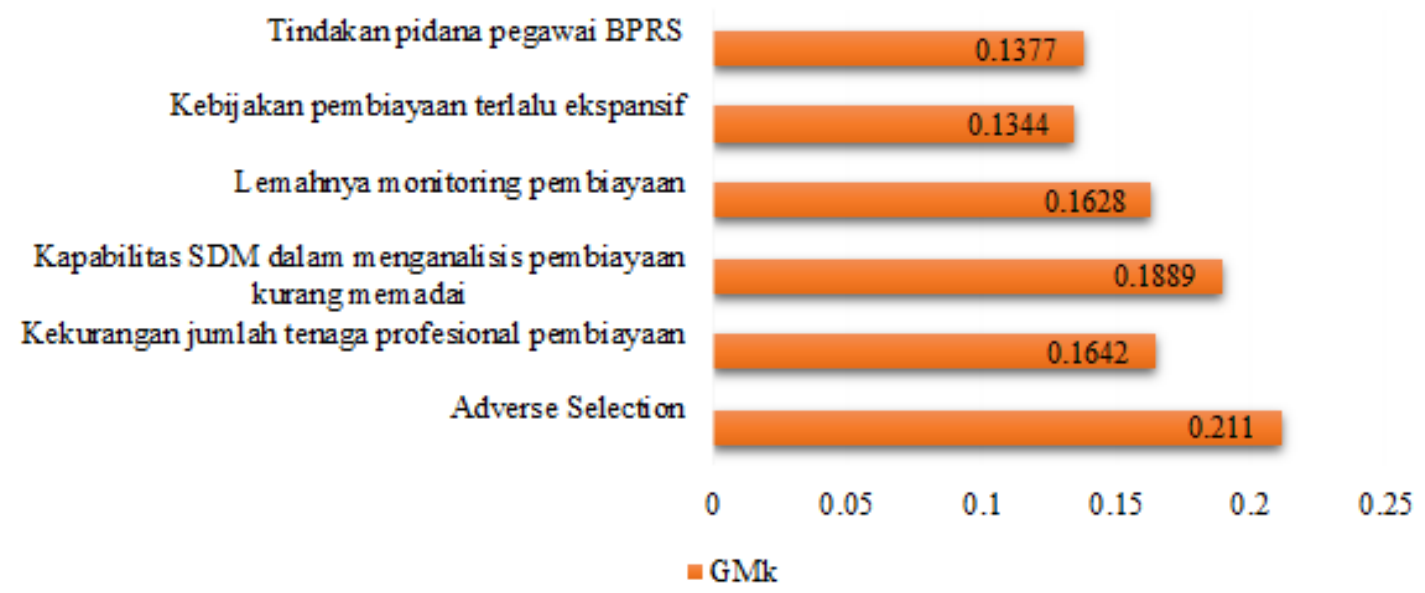

Sumber: Data primer, 2019 (diolah)

Gambar 7 Prioritas penyebab internal pembiayaan bermasalah

\section{Adverse selection}

Penyebab internal yang menempati prioritas pertama yaitu adverse selection (salah memilih nasabah) dengan nilai geometric mean sebesar 0.2110. Hal ini menunjukkan adverse selection menjadi penyebab internal yang memiliki pengaruh paling besar terhadap terjadinya pembiayaan bermasalah pada BPRS di Kabupaten Bogor.

Adverse selection merupakan kondisi yang menggambarkan adanya asymmetric information di dalam partisipasi pasar yaitu ketika penjual dan pembeli mempunyai informasi yang berbeda. Adverse selection dalam dunia perbankan yaitu suatu permasalahan berupa timbulnya informasi yang berbeda atau asymmetric information sebelum terjadinya penyaluran pembiayaan, sehingga terjadi salah memilih nasabah. Pemilik dana atau shahibul maal dalam hal ini pihak BPRS tidak mengetahui secara jelas dan rinci terkait karakteristik calon nasabahnya sehingga terjadi salah memilih nasabah. Nasabah yang terpilih adalah nasabah dengan kualitas buruk yang berpotensi menyumbang angka pembiayaan bermasalah pada BPRS tersebut. Oleh karena itu, dalam lingkungan dengan asymmetric information yang tinggi, bank syariah tidak terlindungi dari tingkat risiko kredit yang tinggi (Lassoued, 2018).

\section{Kapabilitas SDM dalam menganalisis pembiayaan kurang memadai}

Penyebab internal yang menempati prioritas kedua yaitu kapabilitas SDM dalam menganalisis pembiayaan kurang memadai dengan nilai geometric mean sebesar 0.1889. Analisis pembiayaan merupakan suatu langkah awal dalam rangkaian penyaluran pembiayaan yang dilakukan oleh pihak bank syariah. Kualitas analisis pembiayaan yang baik atau dalam kata lain keberhasilan dari analisis pembiayaan dapat memberikan dampak positif terhadap kelancaran proses pengembalian pinjaman berupa pembayaran angsuran oleh nasabah terhadap pihak bank, begitu pula sebaliknya (Susilo, 2017). Apabila kualitas dari analisis pembiayaan buruk, maka akan timbul risiko kemacetan dalam angsuran nasabah. Prinsip kehati-hatian dalam proses analisis sangat dibutuhkan guna meminimalisasi risiko kemacetan tersebut, terutama dalam hal pengumpulan informasi dan data yang diperlukan.

\section{Kekurangan jumlah tenaga profesional pembiayaan}

Penyebab internal yang menempati prioritas ketiga yaitu kurangnya jumlah tenaga profesional bidang pembiayaan dengan nilai geometric mean sebesar 0.1642. Menurut para praktisi, tenaga profesional pembiayaan di BPRS memang sangat terbatas jumlahnya. Setiap tenaga pembiayaan harus memegang kendali terhadap banyak nasabah sehingga pengendalian akan pembiayaan tidak maksimal. 
Keterbatasan tenaga pembiayaan ini dapat menjadi pemicu terhadap timbulnya pembiayaan bermasalah pada BPRS tersebut.

\section{Lemahnya monitoring pembiayaan}

Penyebab internal yang menempati prioritas keempat yaitu lemahnya monitoring pembiayaan dengan nilai geometric mean sebesar 0.1628. Kegiatan monitoring pada perbankan dimaksudkan untuk penjagaan dan pengamanan terhadap kekayaan bank yang disalurkan melalui pembiayaan kepada nasabah. Menurut Djamil (2012), lemahnya pemantauan yang merupakan salah satu aspek manajerial bank dapat menjadi pemicu timbulnya pembiayaan bermasalah. Hal ini disebabkan luasnya lingkup pembiayaan serta adanya keterbatasan waktu dan tenaga kerja atau SDM.

\section{Tindakan pidana pegawai BPRS}

Penyebab internal yang menempati prioritas kelima yaitu tindakan pidana pegawai BPRS dengan nilai geometric mean sebesar 0.1377. Penyaluran pembiayaan yang tidak dilandaskan prinsip kehati-hatian (prudent) merupakan salah satu hal yang mampu menimbulkan terjadinya kredit macet atau pembiayaan bermasalah (Anisha, 2016). Menurut para responden, tindakan pidana di sini diartikan dengan adanya pembiayaan fiktif. Pembiayaan fiktif ini terjadi karena adanya manipulasi terhadap permohonan pembiayaan (Ibrahim \& Rahmati, 2017).

\section{Kebijakan pembiayaan terlalu ekspansif}

Penyebab internal yang menempati prioritas keenam yaitu kebijakan pembiayaan yang terlalu ekspansif dengan nilai geometric mean sebesar 0.1344. Penerapan kebijakan piutang yang kurang tepat berpotensi memicu terjadinya pembiayaan bermasalah pada perbankan syariah (Djamil, 2012). Menurut Siamat, Kusumawardhani \& Agustin (2005), penetapan target kredit yang melebihi pertumbuhan kredit secara wajar berakibat kepada penyaluran kredit secara tidak selektif. Ketidakselektifan petugas pembiayaan dalam memilih calon nasabah pembiayaan dapat berujung kepada timbulnya pembiayaan bermasalah.

\section{Penyebab Eksternal Pembiayaan Bermasalah}

Penyebab eksternal merujuk kepada penyebab yang berasal dari luar bank syariah. Penyebab eksternal berasal dari nasabah atau kondisi lain di luar bank. Penyebab eksternal terdiri dari kondisi ekonomi dan politik, kemudahan dalam memperoleh pembiayaan, kondisi usaha nasabah yang memburuk, iktikad tidak baik dari nasabah, penggunaan dana yang tidak sesuai akad, dan permasalahan personal nasabah.

Gambar 8 menunjukkan tingkat prioritas penyebab eksternal penyumbang angka pembiayaan bermasalah pada BPRS di Kabupaten Bogor berdasarkan hasil olahan data yang diperoleh. Prioritas pertama yaitu iktikad tidak baik dari nasabah pembiayaan dengan nilai geometric mean sebesar 0.2547. Urutan kedua yaitu kondisi usaha nasabah yang menurun dengan nilai geometric mean sebesar 0.2092. Urutan ketiga yaitu penggunaan dana tidak sesuai akad dengan nilai geometric mean sebesar 0.1863. Urutan keempat yaitu permasalahan personal nasabah dengan nilai geometric mean sebesar 0.1465. Urutan kelima yaitu kemudahan memperoleh pembiayaan dengan nilai geometric mean sebesar 0.1252. Urutan keenam yaitu kondisi ekonomi dan politik dengan nilai geometric mean sebesar 0.0781. Nilai $\mathrm{W}$ yang dihasilkan dari perhitungan rater agreement sebesar 0.2503. Hal ini berarti tingkat kesepakatan responden mencapai $25.03 \%$. 


\section{PENYEBAB EKSTERNAL}

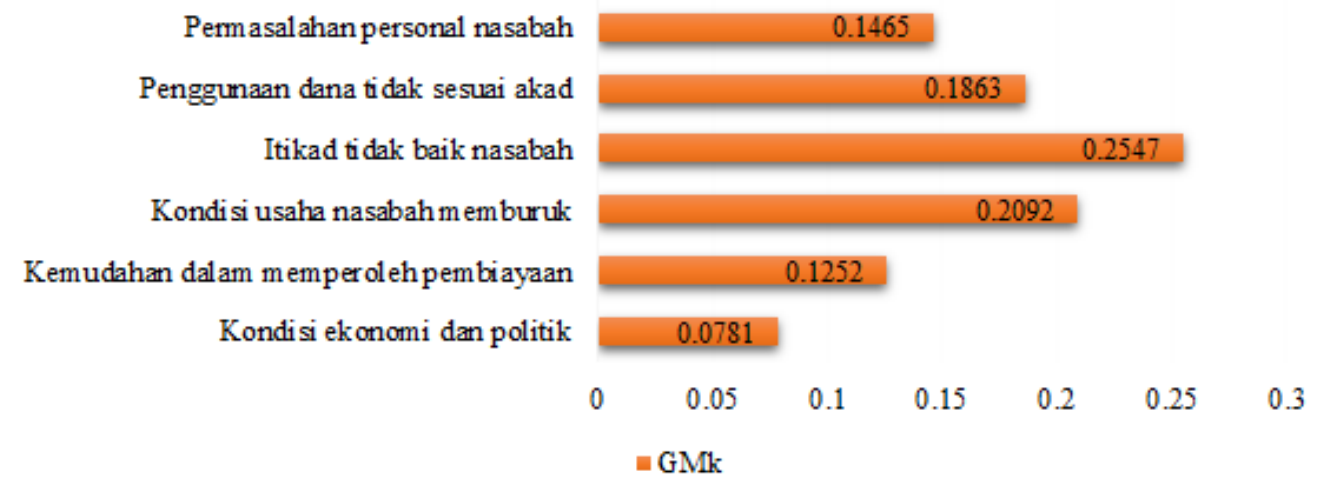

Sumber: Data primer, 2019 (diolah)

Gambar 8 Prioritas penyebab eksternal pembiayaan bermasalah

\section{Iktikad tidak baik nasabah pembiayaan}

Penyebab eksternal yang menempati prioritas pertama yaitu iktikad tidak baik nasabah pembiayaan dengan nilai geometric mean sebesar 0.2547 . Hal ini menunjukkan adanya iktikad tidak baik dari nasabah pembiayaan menjadi penyebab eksternal yang memiliki pengaruh paling besar terhadap terjadinya pembiayaan bermasalah pada BPRS di Kabupaten Bogor.

Menurut para responden, iktikad tidak baik nasabah terbukti dari penundaan sampai dengan keengganan nasabah membayar cicilan pembiayaan kepada pihak BPRS. Selain itu, pembiayaan berbasis equity financing (pembiayaan modal) sangat rentan dalam menyumbang angka pembiayaan bermasalah. Hal ini disebabkan pemberian kebebasan kepada mudharib (pengelola modal) dalam hal ini nasabah dalam mengelola dana yang dipinjamkan oleh pihak BPRS. Oleh sebab itu, BPRS lebih berpihak kepada pembiayaan berbasis debt financing (pembiayaan dengan utang) seperti murabahah, salam, dan istishna.

\section{Kondisi usaha nasabah memburuk}

Penyebab eksternal yang menempati prioritas kedua yaitu kondisi usaha nasabah yang memburuk dengan nilai geometric mean sebesar 0.2092. Kondisi usaha nasabah yang menurun disebabkan adanya penurunan penghasilan atau pendapatan nasabah peminjam (debitur). Berdasarkan hasil penelitian yang dilakukan oleh Azis (2013), nasabah yang mengalami kegagalan dalam pengembalian pembiayaan kepada pihak bank memang dihadapkan kepada masalah penjualan sehingga penghasilan pun ikut menurun.

\section{Penggunaan dana tidak sesuai akad}

Penyebab eksternal yang menempati prioritas ketiga yaitu penggunaan dana tidak sesuai akad dengan nilai geometric mean sebesar 0.1863 . Menurut responden, beberapa kasus pembiayaan bermasalah timbul akibat penyalahgunaan dana yang dipinjam oleh pihak nasabah. Nasabah menggunakan dananya untuk keperluan yang tidak sesuai dengan akad. Menurut Ibrahim \& Rahmati (2017), hal ini terjadi dikarenakan adanya perwakilan dalam pembelian barang. Seharusnya pembelian barang dilakukan oleh bank, namun hal ini sering kali diwakilkan kepada nasabah.

\section{Permasalahan personal nasabah}

Penyebab eksternal yang menempati prioritas keempat yaitu permasalahan personal nasabah dengan nilai geometric mean sebesar 0.1465 . Timbulnya permasalahan personal pada nasabah dapat menjadi salah satu faktor terjadinya pembiayaan bermasalah. Permasalahan personal yang sering dihadapi nasabah yaitu perceraian, kematian, sakit, dan gaya hidup yang boros (Susilo, 2017). Menurut para praktisi, perceraian menjadi salah satu penyebab yang paling banyak berpengaruh terhadap 
pembiayaan bermasalah. Hal ini disebabkan timbulnya saling lempar tanggung jawab di antara pasangan yang melakukan pembiayaan kepada pihak bank.

\section{Kemudahan memperoleh pembiayaan}

Penyebab eksternal yang menempati prioritas kelima yaitu kemudahan memperoleh pembiayaan dengan nilai geometric mean sebesar 0.1252 . Menurut para praktisi, timbulnya asumsi di masyarakat bahwa pengajuan pembiayaan kepada BPRS lebih mudah dibanding melakukan pengajuan pembiayaan kepada bank umum syariah, menjadi salah satu faktor yang menyebabkan terjadinya pembiayaan bermasalah pada BPRS di Kabupaten Bogor. Nasabah yang ditolak oleh bank umum syariah menjadikan BPRS sebagai pilihan kedua untuk mengajukan pembiayaan. Selain itu, persyaratan pembiayaan yang diajukan oleh pihak BPRS kepada calon nasabah tidak sebanyak persyaratan yang diajukan oleh pihak bank umum syariah kepada nasabahnya. Menurut praktisi, hal ini menjadi alasan para calon nasabah dengan kualitas kurang baik mengajukan pembiayaan pada BPRS.

\section{Kondisi ekonomi dan politik}

Penyebab eksternal yang menempati prioritas keenam yaitu kondisi ekonomi, politik, dan keamanan dengan nilai geometric mean sebesar 0.0781. Menurut Anisha (2016), kondisi ekonomi suatu negara dapat memicu terjadinya pembiayaan bermasalah karena memberikan pengaruh bagi kelancaran usaha nasabah. Apabila kondisi ekonomi negara baik, maka akan berdampak kepada kelancaran usaha nasabah. Sebaliknya, apabila kondisi ekonomi negara memburuk, maka akan berdampak kepada penurunan penghasilan nasabah sehingga nasabah akan sulit melakukan angsuran kepada pihak bank.

Selain itu, perubahan politik dalam negeri menjadi salah satu faktor pembiayaan bermasalah. Menurut salah satu praktisi, kondisi politik negara khususnya pada musim politik, juga berpengaruh terhadap pengembalian dana oleh nasabah kepada pihak BPRS. Nasabah yang mendukung salah satu calon legislatif misalnya. Nasabah tersebut akan rela mengeluarkan dana untuk mendukung calon legislatif yang ia dukung. Hal ini secara tidak langsung berdampak kepada pengembalian pinjaman.

\section{Solusi Pembiayaan Bermasalah}

Solusi untuk mengatasi penyebab terjadinya pembiayaan bermasalah pada BPRS di Kabupaten Bogor terbagi ke dalam dua kelompok yaitu solusi internal dan solusi eksternal. Nilai geometric mean (GMk) dari penyebab eksternal adalah sebesar 0.8, sedangkan untuk nilai geometric mean (GMk) penyebab internal sebesar 0.2. Hal tersebut mengindikasi bahwa solusi yang paling berpengaruh dalam mengatasi pembiayaan bermasalah pada BPRS di Kabupaten Bogor menurut para responden yaitu solusi eksternal, sehingga solusi eksternal harus mendapat perhatian khusus dan lebih utama dijalankan oleh pihak bank agar pembiayaan bermasalah pada BPRS dapat dikendalikan dan dicegah. Nilai W yang dihasilkan dari perhitungan rater agreement adalah 1, yang berarti responden 100\% sepakat akan hal ini atau dalam kata lain seluruh responden sepakat bahwa solusi eksternal merupakan prioritas solusi atas penyebab pembiayaan bermasalah yang terjadi pada BPRS di Kabupaten Bogor.

\section{SOLUSI}

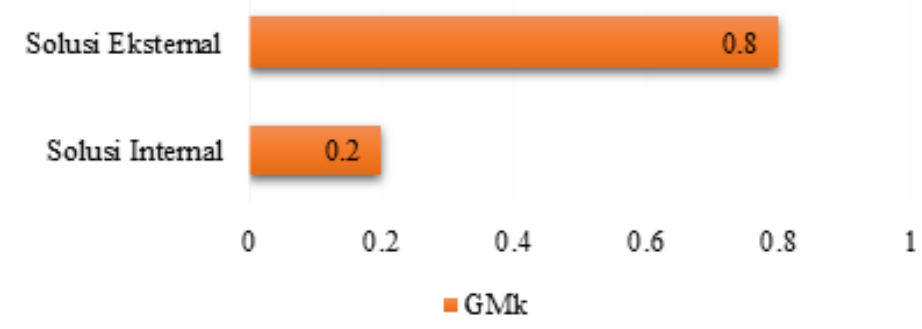

Sumber: Data primer, 2019 (diolah)

Gambar 9 Prioritas solusi pembiayaan bermasalah 


\section{Solusi Internal Pembiayaan Bermasalah}

Solusi internal bermaksud untuk mengatasi penyebab internal pembiayaan bermasalah pada BPRS di Kabupaten Bogor. Solusi internal terdiri dari pengecekan SOP pembiayaan secara sistematis, menata sistem perekrutan, pelatihan bagi petugas pembiayaan, meningkatkan intensitas monitoring, evaluasi terhadap kebijakan pembiayaan, serta pengawasan internal dari kepala bagian pembiayaan.

Gambar 10 menunjukkan tingkat prioritas solusi internal untuk mengatasi penyebab internal terjadinya pembiayaan bermasalah pada BPRS di Kabupaten Bogor berdasarkan hasil olahan data yang diperoleh. Prioritas pertama yaitu pelatihan bagi petugas pembiayaan dengan nilai geometric mean sebesar 0.2346. Urutan kedua yaitu pengawasan internal dari kepala bagian pembiayaan dengan nilai geometric mean sebesar 0.1572 . Urutan ketiga yaitu meningkatkan intensitas monitoring dengan nilai geometric mean sebesar 0.1562 . Urutan keempat yaitu evaluasi terhadap kebijakan pembiayaan dengan nilai geometric mean sebesar 0.1556. Urutan kelima yaitu pengecekan SOP pembiayaan secara sistematis dengan nilai geometric mean sebesar 0.1547. Urutan keenam yaitu menata sistem perekrutan dengan nilai geometric mean sebesar 0.1417. Nilai W yang dihasilkan dari perhitungan rater agreement sebesar 0.1406 . Hal ini berarti tingkat kesepakatan responden mencapai $14.06 \%$.

\section{SOLUSI INTERNAL}

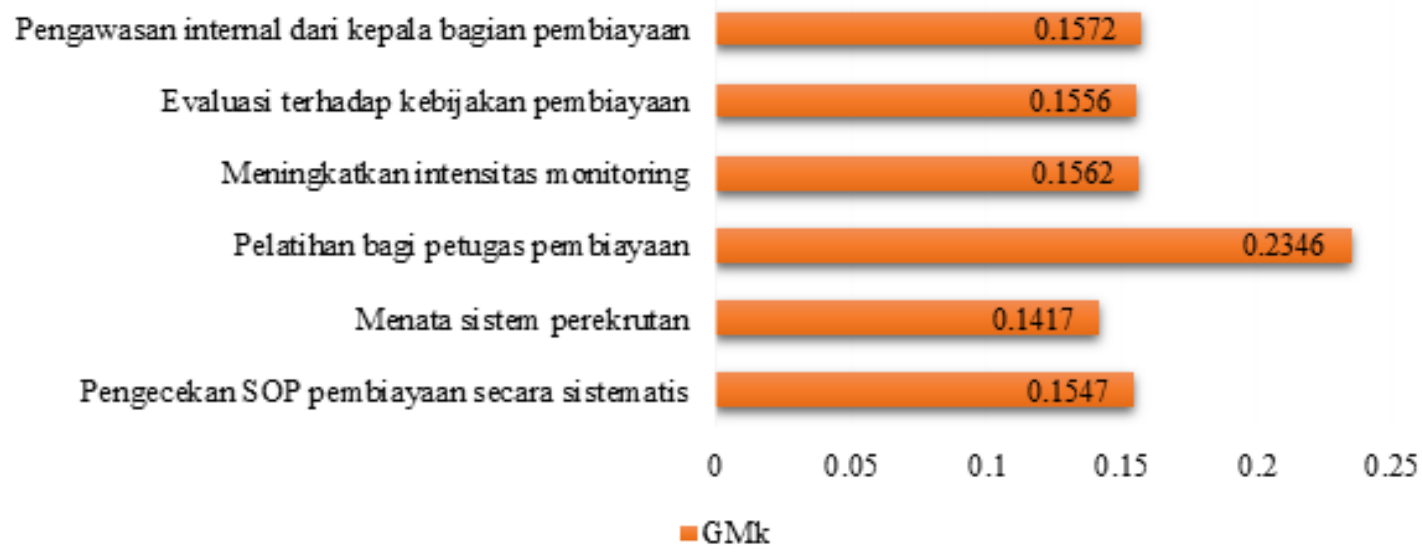

Sumber: Data primer, 2019 (diolah)

Gambar 10 Prioritas solusi internal pembiayaan bermasalah

\section{Pelatihan bagi petugas pembiayaan}

Solusi internal yang menempati prioritas pertama yaitu pelatihan bagi petugas pembiayaan dengan nilai geometric mean sebesar 0.2346 . Hal ini menunjukkan pelatihan bagi petugas pembiayaan menjadi solusi atas penyebab internal yang memiliki peranan paling besar dalam mengatasi terjadinya pembiayaan bermasalah pada BPRS di Kabupaten Bogor. Pelatihan terkait analisis pembiayaan yang baik dan benar sangat dibutuhkan untuk mengatasi permasalahan dalam memilih calon nasabah pembiayaan. Seorang petugas pembiayaan khususnya analis, harus mampu memperkirakan risiko atas penyaluran pembiayaan. Ketepatan analis dalam menganalisis sangat memengaruhi kualitas dari pengembalian pinjaman nasabah yang bersangkutan.

\section{Pengawasan internal dari kepala bagian pembiayaan}

Solusi internal yang menempati prioritas kedua yaitu pengawasan internal dari kepala bagian pembiayaan dengan nilai geometric mean sebesar 0.1572. Pengawasan internal yang dilakukan oleh kepala bagian pembiayaan kepada anak buahnya selaku pengawas langsung nasabah pembiayaan sangat dibutuhkan. Kepala bagian pembiayaan bertanggung jawab untuk memastikan bahwa petugas pembiayaan melakukan tugasnya sesuai dengan kebijakan yang berlaku dan terhindar dari perbuatanperbuatan menyimpang yang dapat merugikan BPRS. Menurut Rustam (2013), pengendalian internal 
diperlukan untuk mengevaluasi proses pembiayaan yang disalurkan secara keseluruhan serta menilai ketepatan kegiatan pengawasan yang dilakukan oleh account officer (pegawai pengelola pembiayaan nasabah).

\section{Meningkatkan intensitas monitoring}

Solusi internal yang menempati prioritas ketiga yaitu meningkatkan intensitas monitoring dengan nilai geometric mean sebesar 0.1562. Kegiatan monitoring dari pihak BPRS kepada nasabah sangat diperlukan pasca pencairan pembiayaan. Hal ini dapat dijadikan sebagai alat deteksi dini dalam mereduksi risiko kemacetan pengembalian pembiayaan nasabah (Susilo, 2017). Oleh karena itu, peningkatan intensitas monitoring sangat tepat dalam mengatasi permasalahan lemahnya pengawasan yang dapat berujung kepada timbulnya pembiayaan bermasalah.

\section{Evaluasi terhadap kebijakan pembiayaan}

Solusi internal yang menempati prioritas keempat yaitu evaluasi terhadap kebijakan pembiayaan dengan nilai geometric mean sebesar 0.1556. Kebijakan pembiayaan BPRS yang tidak tepat dapat memberikan dampak yang buruk terhadap bank itu sendiri, salah satunya adalah pembiayan bermasalah. Evaluasi kebijakan yang dilakukan tidak hanya terkait dengan teknis penyaluran pembiayaan saja, tetapi juga evaluasi terhadap kebijakan yang berkaitan langsung dengan petugas penyalur pembiayaan.

\section{Pengecekan SOP pembiayaan secara sistematis}

Solusi internal yang menempati prioritas kelima yaitu pengecekan SOP pembiayaan secara sistematis dengan nilai geometric mean sebesar 0.1547. Risiko pembiayaan akan dapat direduksi bila petugas pembiayaan bekerja sesuai SOP BPRS dan ketentuan regulator. Kegiatan pengecekan SOP pembiayaan berupa syarat administratif secara sistematis dapat membantu dalam meminimalisasi terjadinya pembiayaan bermasalah. Hal ini disebabkan pembiayaan tersebut telah melalui proses yang sesuai dengan ketentuan yang telah ditetapkan pihak BPRS.

\section{Menata sistem perekrutan}

Solusi internal yang menempati prioritas keenam yaitu menata sistem perekrutan dengan nilai geometric mean sebesar 0.1417. Terdapat beberapa tahap yang harus dilalui untuk memperoleh SDM profesional untuk suatu bidang tertentu. Tahapan tersebut dimulai dengan proses rekrutmen. Rekrutmen yang baik akan memudahkan dalam proses seleksi guna mendapatkan SDM andal dengan kinerja yang baik. Menurut Yullyanti (2011), kinerja tidak hanya dipengaruhi oleh proses seleksi, namun erat kaitannya dengan proses rekrutmen secara tidak langsung.

\section{Solusi Eksternal Pembiayaan Bermasalah}

Solusi eksternal bermaksud untuk mengatasi penyebab eksternal atas terjadinya pembiayaan bermasalah pada BPRS di Kabupaten Bogor. Solusi eksternal terdiri dari meningkatkan pelayanan, penyeleksian nasabah pembiayaan secara cermat, supervisi usaha nasabah, penguatan analisis awal, edukasi dan monitoring penggunaan dana, serta pendekatan personal nasabah.

Gambar 11 menunjukkan tingkat prioritas solusi eksternal untuk mengatasi penyebab eksternal terjadinya pembiayaan bermasalah pada BPRS di Kabupaten Bogor berdasarkan hasil olahan data yang diperoleh. Prioritas pertama yaitu penguatan analisis awal dengan nilai geometric mean sebesar 0.2053. Urutan kedua yaitu edukasi dan monitoring penggunaan dana dengan nilai geometric mean sebesar 0.1931. Urutan ketiga yaitu menyeleksi nasabah pembiayaan secara cermat dengan nilai geometric mean sebesar 0.1853. Urutan keempat yaitu supervisi usaha nasabah dengan nilai geometric mean sebesar 0.1759. Urutan kelima yaitu pendekatan personal nasabah dengan nilai geometric mean sebesar 0.1567. Urutan keenam yaitu meningkatkan pelayanan dengan nilai geometric mean sebesar 0.0837. Nilai W yang dihasilkan dari perhitungan rater agreement sebesar 0.4331. Hal ini berarti tingkat kesepakatan responden mencapai $43.31 \%$. 


\section{SOLUSI EKSTERNAL}

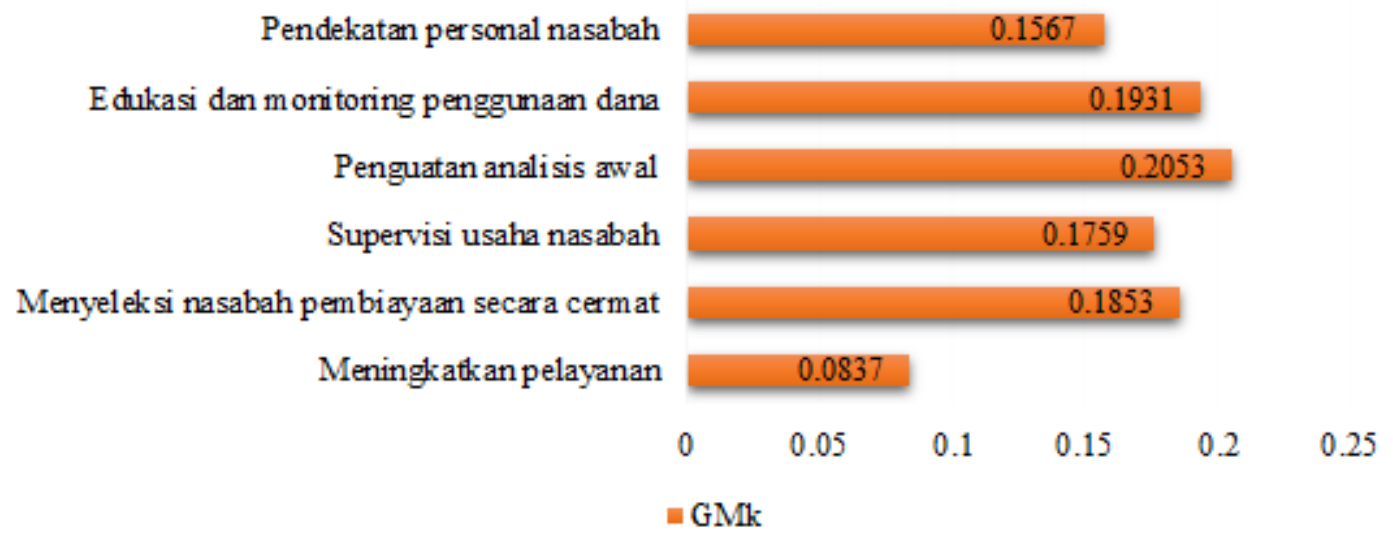

Sumber: Data primer, 2019 (diolah)

Gambar 11 Prioritas solusi eksternal pembiayaan bermasalah

\section{Penguatan analisis awal}

Solusi eksternal yang menempati prioritas pertama yaitu penguatan analisis awal dengan nilai geometric mean sebesar 0.2053 . Hal ini menunjukkan bahwa melakukan penguatan analisis di awal menjadi solusi atas penyebab eksternal yang paling memiliki peranan dalam mengatasi terjadinya pembiayaan bermasalah pada BPRS di Kabupaten Bogor. Salah satu penyebab terjadinya pembiayaan bermasalah adalah analisis awal pembiayaan yang kurang tajam. Hal ini merupakan salah satu dari sekian penyebab yang dapat berpengaruh terhadap timbulnya pembiayaan bermasalah dari aspek operasional bank. Oleh karena itu, penguatan dari segi analisis sangat diperlukan. Analisis yang tepat perlu dilakukan baik yang bersifat kuantitatif maupun kualitatif.

\section{Edukasi dan monitoring penggunaan dana}

Solusi eksternal yang menempati prioritas kedua yaitu edukasi dan monitoring penggunaan dana dengan nilai geometric mean sebesar 0.1931. Penggunaan dana oleh nasabah yang tidak sesuai dengan kesepakatan yang diperjanjikan dengan pihak BPRS berdampak buruk kepada BPRS. Hal ini dapat memicu terjadinya pembiayaan bermasalah yang dapat merugikan pihak BPRS. Oleh karena itu, edukasi di awal perjanjian terkait dana yang akan disalurkan sangat penting. Selanjutnya monitoring penggunaan dana juga diperlukan sebagai bentuk kontinuitas dari pengendalian penggunaan dana tersebut.

\section{Menyeleksi nasabah pembiayaan secara cermat}

Solusi eksternal yang menempati prioritas ketiga yaitu menyeleksi nasabah pembiayaan secara cermat dengan nilai geometric mean sebesar 0.1853. Penyeleksian calon nasabah secara cermat berjalan seiringan dengan proses analisis yang dilakukan secara tepat dan akurat. Apabila kedua hal tersebut dilakukan dengan baik, maka akan berdampak kepada terciptanya pembiayaan yang berkualitas. Penerapan standar pinjaman yang ketat akan membantu dalam proses pencegahan terjadinya pembiayaan bermasalah (Aysan \& Disli, 2019).

\section{Supervisi usaha nasabah}

Solusi eksternal yang menempati prioritas keempat yaitu supervisi usaha nasabah dengan nilai geometric mean sebesar 0.1759. Optimalisasi supervisi yang dilakukan diharapkan dapat meningkatkan kepekaan petugas pembiayaan terhadap setiap perubahan yang terjadi pada usaha nasabahnya. Hal ini selain memberikan keuntungan kepada pihak BPRS, juga berfungsi sebagai bentuk pelayanan BPRS kepada nasabahnya yang mampu membedakan bank syariah dengan bank konvensional. 


\section{Pendekatan personal nasabah}

Solusi eksternal yang menempati prioritas kelima yaitu pendekatan personal nasabah dengan nilai geometric mean sebesar 0.1567. Upaya ini dinilai akan mampu menjadi salah satu solusi mengatasi pembiayaan bermasalah yang disebabkan adanya permasalahan personal yang dialami nasabah. Pendekatan personal yang dilakukan oleh pihak BPRS khususnya petugas pembiayaan berfungsi untuk mengetahui kondisi nasabah secara lebih mendalam. Selain itu, upaya ini berfungsi sebagai bentuk silaturahmi pihak BPRS kepada nasabah pembiayaan yang bersangkutan.

\section{Meningkatkan pelayanan}

Solusi eksternal yang menempati prioritas keenam yaitu meningkatkan pelayanan dengan nilai geometric mean sebesar 0.0837. Peningkatan kualitas pelayanan yang diberikan oleh pihak bank kepada nasabah sangat diperlukan di tengah persaingan yang semakin kompetitif (Tatik, 2017). Salah satu dimensi kualitas layanan yaitu daya tanggap (ketanggapan) berfungsi dalam menindaklanjuti keluhan yang disampaikan nasabah, sebagai contoh yang ada kaitannya dengan kondisi ekonomi dan juga politik.

\section{Strategi Pencegahan Pembiayaan Bermasalah}

Rumusan strategi disusun berdasarkan studi literatur dan indepth interview (wawancara mendalam) kepada para responden. Strategi-strategi ini diharapkan mampu menjadi rujukan cara yang dapat ditempuh oleh bank syariah khususnya BPRS di wilayah Kabupaten Bogor untuk mencegah terjadinya pembiayaan bermasalah. Strategi yang dirumuskan terdiri dari enam strategi yaitu pembentukan komite pembiayaan, penyusunan mitigasi risiko pembiayaan, pembekalan petugas pembiayaan, pemberian reward (penghargaan) dan punishment (hukuman) petugas pembiayaan, optimalisasi pengawasan, dan kunjungan rutin ke nasabah.

Gambar 12 menunjukkan tingkat prioritas strategi pencegahan pembiayaan bermasalah pada BPRS di Kabupaten Bogor berdasarkan hasil olahan data yang diperoleh. Prioritas pertama yaitu penyusunan mitigasi risiko pembiayaan dengan nilai geometric mean sebesar 0.2664 . Urutan kedua yaitu pembekalan petugas pembiayaan dengan nilai geometric mean sebesar 0.2379 . Urutan ketiga yaitu pembentukan komite pembiayaan yang menangani pembiayaan bermasalah dengan nilai geometric mean sebesar 0.2211. Urutan keempat yaitu kunjungan rutin ke nasabah dengan nilai geometric mean sebesar 0.1085. Urutan kelima yaitu optimalisasi pengawasan dengan nilai geometric mean sebesar 0.1020 . Urutan keenam yaitu pemberian reward dan punishment bagi petugas pembiayaan dengan nilai geometric mean sebesar 0.0642 . Nilai W yang dihasilkan dari perhitungan rater agreement sebesar 0.4169. Hal ini berarti tingkat kesepakatan responden mencapai $41.69 \%$.

\section{STRATEGI}

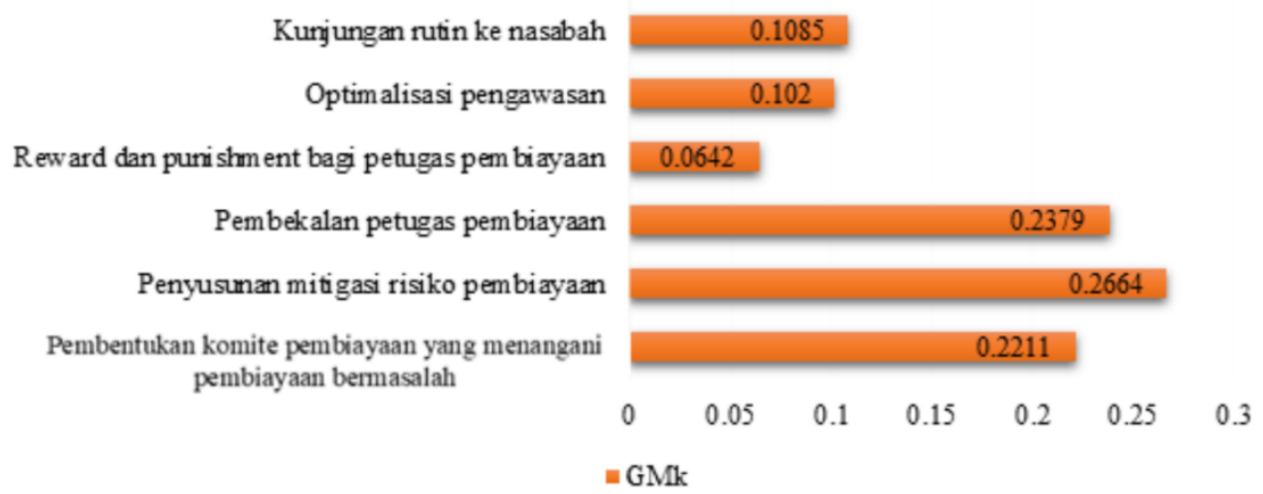

Sumber: Data primer, 2019 (diolah)

Gambar 12 Prioritas strategi pencegahan pembiayaan bermasalah 


\section{Penyusunan mitigasi risiko pembiayaan}

Strategi pencegahan pembiayaan bermasalah pada BPRS di Kabupaten Bogor yang menempati prioritas pertama yaitu penyusunan mitigasi risiko pembiayaan dengan nilai geometric mean sebesar 0.2664. Hal ini menunjukkan bahwa menurut para responden penyusunan mitigasi risiko pembiayaan menjadi strategi yang memiliki peranan paling besar dalam mencegah terjadinya pembiayaan bermasalah pada BPRS di Kabupaten Bogor.

Mitigasi risiko pembiayaan merupakan upaya dalam mengelola risiko yang timbul akibat penyaluran pembiayaan kepada nasabah yang berpotensi menimbulkan kerugian pihak BPRS. Mitigasi risiko bertujuan untuk meminimalkan dampak kerugian tersebut. Menurut Susilo (2017), mitigasi risiko menggunakan teknik dalam perumusannya. Teknik-teknik tersebut adalah model pemeringkatan untuk nasabah pembiayaan perorangan, manajemen portofolio pembiayaan, agunan, pengawasan arus kas, manajemen pemulihan, dan asuransi. Hal-hal dalam manajemen risiko berdasarkan Peraturan Bank Indonesia No 13/23/PBI/2011 mencakup: pengawasan aktif yang dilakukan oleh dewan komisaris, direksi dan DPS, penentuan kebijakan prosedur dan penetapan limit, melakukan proses identifikasi, pengukuran, pemantauan, pengendalian risiko, dan SIM (Sistem Informasi Manajemen) risiko kredit, serta melakukan sistem pengendalian internal yang menyeluruh.

\section{Pembekalan petugas pembiayaan}

Strategi pencegahan pembiayaan bermasalah pada BPRS di Kabupaten Bogor yang menempati prioritas kedua yaitu pembekalan petugas pembiayaan dengan nilai geometric mean sebesar 0.2379. Demi terciptanya pembiayaan yang berkualitas, proses seleksi nasabah harus dilakukan secara akurat. Oleh karena itu, diperlukan kemampuan analisis yang baik dari petugas pembiayaan khususnya analis. Pembekalan terkait teknis penyaluran pembiayaan sangat penting untuk dilakukan. Pembekalan petugas pembiayaan tersebut didapatkan dari training-training (pelatihan-pelatihan) baik yang bersifat internal maupun eksternal. BPRS di Kabupaten Bogor selalu berusaha memberikan pelatihan secara rutin guna meningkatkan kualitas karyawannya. Selain itu, berdasarkan wawancara yang dilakukan kepada para praktisi, penanaman nilai spiritual sangatlah penting untuk dilakukan. Hal ini yang menjadi nilai tambah bank syariah. Dalam kata lain, penerapan prinsip syariah harus secara mutlak dijadikan pedoman dalam segala aktivitas perbankan.

\section{Pembentukan komite pembiayaan yang menangani pembiayaan bermasalah}

Strategi pencegahan pembiayaan bermasalah pada BPRS di Kabupaten Bogor yang menempati prioritas ketiga yaitu pembentukan komite pembiayaan yang menangani pembiayaan bermasalah dengan nilai geometric mean sebesar 0.2211. Komite pembiayaan merupakan suatu lembaga yang ada dalam bank syariah tersebut yang menangani khusus terkait pembiayaan. Komite pembiayaan berwenang dalam memberikan putusan atas permohonan pembiayaan yang diajukan oleh nasabah. Komite pembiayaan yang khusus menangani pembiayaan bermasalah pada beberapa BPRS di Kabupaten Bogor dinamakan tim remedial.

Secara umum, fungsi dan tugas dari komite pembiayaan adalah melakukan pembahasan atas proposal pembiayaan yang diajukan oleh account officer (pegawai pengelola pembiayaan nasabah), memutuskan persetujuan atau penolakan atas pembiayaan yang diajukan, merumuskan langkah untuk menyelesaikan pembiayaan bermasalah, serta memutuskan tingkat kolektabilitas nasabah. Menurut Susilo (2017), profesionalisme anggota komite sangat menentukan kualitas pembiayaan.

\section{Kunjungan rutin ke nasabah}

Strategi pencegahan pembiayaan bermasalah pada BPRS di Kabupaten Bogor yang menempati prioritas keempat yaitu kunjungan rutin ke nasabah pembiayaan dengan nilai geometric mean sebesar 0.1085. Rustam (2013) menyatakan bahwa salah satu penyebab terjadinya pembiayaan bermasalah adalah tidak dilakukannya kunjungan rutin kepada nasabah. Hal ini sangat penting dilakukan sebagai salah satu upaya pemantauan pembiayaan dari pihak BPRS kepada nasabah. Selain sebagai upaya pemantauan, kunjungan rutin juga berfungsi sebagai upaya menjalin silaturahmi pihak BPRS dan nasabah. Menurut para praktisi, kedekatan pihak BPRS dan nasabah akan berdampak kepada 
keterbukaan nasabah khususnya terkait usaha mereka. Nasabah akan menjadi kooperatif kepada pihak BPRS dalam segala aktivitasnya. Hal inilah yang membedakan BPRS dengan bank-bank lainnya.

\section{Optimalisasi pengawasan}

Strategi pencegahan pembiayaan bermasalah pada BPRS di Kabupaten Bogor yang menempati prioritas kelima yaitu optimalisasi pengawasan dengan nilai geometric mean sebesar 0.1020. Pengawasan terhadap pembiayaan yang diberikan pihak BPRS kepada nasabah merupakan salah satu upaya yang bersifat preventif (pencegahan) dalam mengantisipasi pembiayaan bermasalah (Djamil, 2012). Kegiatan pengawasan adalah suatu keniscayaan yang harus dilakukan untuk menyelamatkan dana nasabah yang tersalurkan melalui pembiayaan. Menurut Muhammad (2016), tujuan dari pengawasan pembiayaan adalah untuk memantau kekayaan bank agar terhindar dari penyelewengan, memastikan kebenaran data administrasi pembiayaan, meningkatkan efisiensi dalam pengelolaan tata laksana usaha nasabah, serta memastikan prosedur pembiayaan dipatuhi. Pengawasan tidak hanya dilakukan kepada nasabah pembiayaan, tetapi juga diterapkan dalam internal bank. Hal ini dilakukan untuk mencegah terjadinya tindakan pidana petugas BPRS berupa penyalahgunaan wewenang.

\section{Pemberian reward dan punishment bagi petugas pembiayaan}

Strategi pencegahan pembiayaan bermasalah pada BPRS di Kabupaten Bogor yang menempati prioritas keenam yaitu pemberian reward dan punishment bagi petugas pembiayaan dengan nilai geometric mean sebesar 0.0642. Menurut Sutrisno (2009), reward adalah balas jasa atas pengorbanan waktu, tenaga, dan pikiran yang diberikan perusahaan kepada karyawannya. Sedangan punishment merupakan ancaman hukuman yang befungsi sebagai pemelihara peraturan serta pemberi pelajaran kepada pelanggar (Mangkunegara, 2005). Kedua hal tersebut berperan dalam peningkatan kualitas kinerja karyawan khususnya dalam tanggung jawab atas tugas yang diberikan. Hal ini sesuai dengan penelitian Suryadilaga, Al Musadieq \& Nurtjahjono (2016) yang menyatakan bahwa reward dan punishment berpengaruh secara signifikan terhadap kinerja karyawan pada PT Telkom Indonesia Witel Jatim Selatan Malang.

\section{SIMPULAN}

Berdasarkan hasil penelitian, maka diperoleh kesimpulan sebagai berikut:

1. Penyebab terjadinya pembiayaan bermasalah pada BPRS di Kabupaten Bogor terbagi ke dalam dua kelompok yaitu internal dan eksternal. Penyebab eksternal dinilai menjadi hal yang paling berpengaruh terhadap terjadinya pembiayaan bermasalah. Prioritas penyebab internal dinilai dari yang paling memiliki pengaruh terhadap pembiayaan bermasalah yaitu adverse selection (salah memilih nasabah), kapabilitas SDM dalam analisis kurang memadai, kurangnya jumlah tenaga profesional pembiayaan, lemahnya monitoring pembiayaan, tindakan pidana pegawai BPRS, serta kebijakan pembiayaan yang terlalu ekspansif. Adapun prioritas penyebab eksternal dari yang paling memiliki pengaruh terhadap pembiayaan bermasalah yaitu iktikad tidak baik nasabah pembiayaan, kondisi usaha nasabah memburuk, penggunaan dana tidak sesuai akad, permasalahan personal nasabah, kemudahan memperoleh pembiayaan, serta kondisi ekonomi dan politik.

2. Solusi dalam mengatasi pembiayaan bermasalah pada BPRS di Kabupaten Bogor terbagi ke dalam dua kelompok yaitu solusi internal dan solusi eksternal. Solusi eksternal paling berpengaruh dalam mengatasi pembiayan bermasalah. Prioritas solusi internal dinilai dari yang paling memiliki pengaruh yaitu pelatihan bagi petugas pembiayaan, pengawasan internal dari kepala bagian pembiayaan, meningkatkan intensitas monitoring, evaluasi terhadap kebijakan pembiayaan, pengecekan SOP pembiayaan secara sistematis, serta menata sistem perekrutan. Adapun prioritas solusi eksternal dinilai dari yang paling memiliki pengaruh yaitu penguatan analisis awal, edukasi dan monitoring penggunaan dana, menyeleksi nasabah pembiayaan secara cermat, supervisi usaha nasabah, pendekatan personal nasabah, serta meningkatkan pelayanan.

3. Prioritas strategi pencegahan pembiayaan bermasalah pada BPRS di Kabupaten Bogor dinilai dari yang paling memiliki pengaruh yaitu penyusunan mitigasi risiko pembiayaan, pembekalan petugas 
pembiayaan, pembentukan komite pembiayaan, kunjungan rutin ke nasabah, optimalisasi pengawasan, serta pemberian reward (penghargaan) dan punishment (hukuman) kepada petugas pembiayaan.

\section{DAFTAR PUSTAKA}

Anisha, N. (2016). Indikasi moral hazard dan adverse selection dalam penyaluran dana pihak ketiga [skripsi]. Jakarta, UIN Syarif Hidayatullah.

Ascarya, Yumanita D. (2011). Determinan dan Persistensi Margin Perbankan Konvensional dan Syariah di Indonesia. Jakarta (ID): Jurnal Ekonomi dan Bisnis Islami Fakultas Ekonomi dan Bisnis Universitas Padjadjaran.

Aysan, A.F. \& Disli, M. (2019). Small business lending and credit risk: Granger causality evidence. Economic Modelling, 83, 245-255.

Azis, R. (2013). Analisis penyebab terjadinya kredit bermasalah pada PD BPR Bank Gotong Royong Kabupaten Tegal. Management Analysis Journal, 2(2), 1-11.

Djamil, F. (2012). Penyelesaian Pembiayaan Bermasalah di Bank Syariah. Jakarta (ID), Sinar Grafika.

Firmansyah, I. (2014). Determinant of non performing loan : The case of Islamic bank in Indonesia. Buletin Ekonomi Moneter dan Perbankan, 17(2), 241-258.

Ibrahim, A. \& Rahmati, A. (2017). Analisis solutif penyelesaian pembiayaan bermasalah di bank syariah: Kajian pada produk murabahah di Bank Muamalat Indonesia Banda Aceh. Iqtishadia: Jurnal Kajian Ekonomi dan Bisnis Islam STAIN Kudus, 10(1), 71-96.

Lassoued, M. (2018). Comparative study on credit risk in Islamic banking institutions: The case of Malaysia. The Quarterly Review of Economics and Finance, 70, 267-278.

Mangkunegara, A.P. (2005). Manajemen Sumber Daya Manusia Perusahaan. Bandung (ID), Remaja Rosdakarya.

Muhamad. (2016). Manajemen Pembiayaan Bank Syariah. Yogyakarta (ID), UPP STIM YKPN.

Rahayu, I.G. \& Hendrianto, H. (2018). Mitigasi risiko pembiayaan pada Bank Perkreditan Rakyat Syariah (BPRS) SAFIR Cabang Curup Kabupaten Rejang Lebong. AL-FALAH: Journal of Islamic Economics, 3(2): 85-106.

Rodoni, A. \& Yaman, B. (2018). Asymmetric information and non-performing financing: Study in the Indonesian Islamic banking industry. Al-Iqtishad Journal of Islamic Economics, 10(2), 416430.

Rustam, B.R. (2013). Manajemen Risiko Perbankan Syariah di Indonesia. Jakarta (ID), Salemba Empat.

Saaty, R.W. 2002. Decision making in complex environment: The Analytic Network Process (ANP) for dependence and feedback. Creative decisions foundation, Pittsburgh, PA.

Siamat, D., Kusumawardhani, P. N. \& Agustin, F. (2005). Manajemen Lembaga Keuangan: Kebijakan Moneter dan Perbankan: Dilengkapi UU No. 10 tahun 1998, UU No. 23 tahun 1999, UU No. 03 tahun 2004. Jakarta (ID), Lembaga Penerbit Fakultas Ekonomi Universitas Indonesia.

Suryadilaga, R.M., Al Musadieq, M. \& Nurtjahjono, G.E. (2016). Pengaruh reward dan punishment terhadap kinerja (Studi pada karyawan PT Telkom Indonesia Witel Jatim Selatan Malang). Jurnal Administrasi Bisnis, 39 (1), 156-163.

Tatik, S. (2017). Manajemen Pemasaran Strategik Bank di Era Global. Jakarta (ID), Prenandamedia Group.

Susilo, E. (2017). Analisis Pembiayaan dan Risiko Perbankan Syariah. Yogyakarta (ID), Pustaka Pelajar.

Sutrisno, E. (2009). Manajemen Sumber Daya Manusia. Jakarta (ID), Kencana Prenada Media Group.

Yullyanti, E. (2011). Analisis proses rekrutmen dan seleksi pada kinerja pegawai. Jurnal Imu Administrasi dan Organisasi, 16(3), 131-139. 